\title{
EXPLORING THE PEOPLE'S ATTITUDE AND BEHAVIOR IN THE TOILETS IN PAKISTAN AND JAPAN
}

\author{
Rie Kondo (Nadia) \\ Institute of South Asia, Heidelberg University, Germany \\ nadipedia@gmail.com \\ Rao Nadeem Alam \\ Assistant Professor, Department of Anthropology \\ Quaid-i-Azam University Islamabad, Pakistan \\ raonadeem@qau.edu.pk
}

\begin{abstract}
This research is an effort to document and discover the difference in attitude and behavior towards toilets and usage in Pakistan and Japan. The aim of this comparative study was to show the similarity and variations of the attitude and behavior of the people in both countries clearly, in addition to it, the history of the development of toilet. The first part of this paper presents literature review which can bring forth the plausible factors that make people hesitant in discussion related to excretions. The second part presents the findings of the survey research based on questionnaire which included both open-end and close-end questions and was conducted with the people in both Pakistan and Japan. The results of two countries were quite contrasting. The last part of this paper includes the analysis. Response to questionnaire was refused by majority of the Pakistanis, whereas Japanese gladly participated in the survey. The results show that there is diversity of the attitude and variation in behavior about the usage of the toilet among participants. We may conclude that the sanitary condition are a major determinant of toilet usage and behavior among people. The significance of this research is that it deals with an underresearched area of mundane. People use toilet every day and it is indeed a universal aspect, however, people's behavior in the toilets and attitudes toward toilets have not been investigated enough by social scientists. It is rare to find the comparative study of toilet itself and people's behavior in the toilet in Pakistan and Japan. This research will help future researchers of anthropology and public hygiene. This research may also help to highlight the significance of public and private hygiene.
\end{abstract}

Keywords: Hygiene, Japan, Pakistan, Toilets, Toilet Habits.

\section{INTRODUCTION}

Personal experience of one of the authors, Rie Kondo, may be the best starting point, "When I relocated to Pakistan two and half years ago, one of my main concerns was about toilet. Most Japanese think of sanitary conditions when they visit countries in Asia and Africa, where most of the toilets are not yet fully equipped. I brought several rolls of toilet paper with illustration and fragrance of flowers when I came to Pakistan, as I had known that there were no rolls of paper in Pakistani toilet as people use water, not paper, to clean the body after using the toilet. Consequently, the drain of the toilet of my first apartment was clogged by the paper I used, so I had to pay 500 rupees to have it repaired."

Looking back at our personal past experience, we used many kinds of toilets. For example, I (Kondo) used toilet which was set on the river in Swat, and I heard people there saying that all the things in a stream of water are clean. I experienced pay toilet in a shopping center in London several years ago which I have never seen in Japan. The elementary school which I went was old public school and its toilet was very dark, so pupils said that ghost of a girl who committed suicide in a toilet room was living there. Toilets are not only physical spaces where people just excrete, but we can regard that it also is a 
sociocultural place. For instance, I (Alam) felt quite shocked when travelled from Istanbul to Ankara, Istanbul is modern and thus majority uses western style sitting toilets whereas Ankara, although the capital city, still reflects Asian-ness because of Asian squat toilets in many buildings. During my travel between Lahore and Islamabad I often use paid toilets because they are cleaner, and it also made the class difference overt between the masses and privileged in Pakistan. I used to keep a bottle of water to be used in public toilets during my stay in Austria, because the public toilets do not have a faucet fixed next to the toilet seat to use water to clean after defecation.

Westerners are often in trouble when using "Asian-style" toilet. As Warner (2004) mentioned, we cannot say which behavior and attitude when we use toilet is right or wrong, as it is the cultural criteria that shapes it. Japan and Pakistan are two cultures apart, comparing them in certain context may reveal interesting facts about the social aspects and cultural criteria among two nations. In this regard, this study will elaborate the cultural and historical background of both countries. In addition to that, this study will present the similarity and differences of the attitudes of the people living in Pakistan and Japan. This study is used phenomenology as methodology and synchronic qualitative survey questionnaire was used to collect data from 24 persons (10 Pakistani and 14 Japanese nationals) using convenience sampling. Criteria for the respondent were that he or she is literate and at least 20 years of age. The hypothesis here is: people use toilet not only for excretion but also for other purposes if the condition of toilet is improved. Then toilet room is not just a limited space just for excretion, but it would be the place which provide free space to the users.

One Japanese friend of mine who has been working in Islamabad for two years once showed me a photo of male toilet which was taken in one shopping mall in Islamabad. He found out that the pots were set at each male toilet for urine. He told me that he had never seen this in his quite a long stay in India either. Very often it is considered that it is odd to talk about toilet itself and how to use it, but in fact we can find diversities in the shape of toilet. In addition to the difference of toilet itself, there may be some diversities in the usage and the behavior in the toilet.

Pakistan is promoting tourism in the current government, but the toilets are not given any significance in this regard. This shortcoming may hamper tourism in Pakistan. It is high time to bring forth the debates that highlight the significance of the toilets for tourism and a better growth of a nation. One of the interesting factors in an informal conversation was mentioned that although every mosque has toilets as part of the mosque complex, but they are either locked or very dirty. Some toilets on Pakistani motorways are operated by Public-Private partnership in which 50 Pakistani rupees are charged for each user and they are well maintained and well provided toilets. These are better because there is more investment and better revenue involved in this venture (Khawar, 2016).

National Highways Authority (NHA) of Pakistan requires every Compressed Natural Gas (CNG) station or petrol pump, that uses NHA right of way, to provide ladies and gents toilets ((NHA), 2004). In October 2018 on the initiative of 'Clean and Green Pakistan' Oil and Gas Regulatory Authority (OGRA) issued warning to the fuel stations to keep toilets/washrooms clean and tidy. However, majority of the toilets are malfunctional and unclean at most of the fuel stations to date.

The questionnaire was distributed twice for Pakistani interlocutors. In the first distribution, data gathered was not enough. When the Pakistani people were approached by the Japanese researcher, they were hesitant as if it is a taboo to talk about such topic. However, when Pakistani researcher approached the Pakistanis; many responded albeit reluctantly. Thus, in the second distribution, the data was gathered by Pakistani from Pakistanis in person. That made interlocutors relatively more responsive. The data used in this paper is representative of both distributed survey questionnaires.

\section{REVIEW OF LITERATURE}

Millenium Development Goals, particulalrly health, requires more research and because existing evidence is scarce - more publications of randomised trials for diseases like diarrhoea are required (Coombes, 2010). This is pertinent to examine the social and cultural dimension of hygene and publish it widely to facilitate the policy and practioners likewise. 
Exploring The People's Attitude and Behavior in The Toilets in Pakistan and Japan

Urban landscape often witnesses the segregation of men and women toilets. "The practice of segregating public toilets on the basis of sex is a microcosm of the operation of sex and gender norms. This practice instantiates beliefs about danger, purity, privacy, heterosexism, and the significance of biological sex (Overall, 2007)." Overall (2007) reported that mensuration and childcare as role-related responsibility of women are the strong arguments in favor of sex segregated toilets. Sex segregated toilets are challenged by many genders non-conformist persons and fathers as single parents require the changing station facilities in public toilets. However, the need of having more and cleaner public toilets is still unmet and therefore, sex segregated, or unisex toilets are relatively a secondary concern. Having sex segregated toilets may increase the job opportunities for female sanitary workers though.

Szczygiel (2015) mentioned in her Japanese report that at least in European countries, people feel hesitation in talking about excretion regarding that it as taboo, however, Japanese people tend to talk about excretion quite openly. In her report, it was analysed that the difference of religion influenced people and resulted in this difference of attitude toward excretion. In Europe, where majority of the people believe in Chiristianity, people in general believe that the physical body is inferior to spirit, so all the things which come out from body are dirty and should be kept in scecret. On the contrary, it was mentioned in a historical record "Nihon Shoki (日本書紀)" (or “The Chronicles of Japan"), which was edited in $720 \mathrm{AD}$, that from feces of Godess, the God of clay appeared. In the study of Warner (2004), it was described that besides gender and psychological issue, religion is also the issue which influences the acceptance and rejection of sanitation system. For example, Muslims use onlly left hand for cleansing after defecation, so the contact with fecal material is limited to the hand that is not used to eat.

Curtis and Biran (2001) described in their research that they gathered data in four counties; India, Burkina Faso, the United Kingdom, and the Netherlands and at international airports to find out what kind of things disgust people. The result showed that the responses were diverse, for example, people in India answered "lower castes, kissing in public, mouse in curry, etc." , and in the Netherlands; "fat people, politicians, dirty old man, etc.". However, there are common points that they all feel disgust to 1) excretions, 2) spoiled food, 3) certain type of people (lower caste people, for example.), 4) behavior against social norms, and 5) particular living creatures (such as snakes, pigs.) So, this research shows there is large diversity in expression of disgust emotion. Defecation excretion is apparently contemporary universal.

Toilet: Religio-Cultural Perspectives in Pakistan

According to Pathak (1995), the remains pf Harappan civilisation showed that people living there used water borne toilets in their houses in $2500 \mathrm{BC}$. It was the fineset sanitary engineering at that time, however, it was dissappeared along with the decline of the Indus Vally civilisation, so since that period, people in this area have been facing sanitary problems. The report of World Bank: The Water and Sanitation Program (2005) mentioned that more than 66 percent of the people in South Asia cannot access sanitation.

Pakistan, a majority Muslim country, it is obvious that religious doctrine influences people's behavior and sagacity of purity like followers of other monotheistic world religions. In Islam, it is mentioned that "Purification is equal to half of the faith" (Sahi Muslim). There are some etiquettes when using toilet, for example, it it considered that when entering the toilet, one should not have something on which the name of Allah or any verse of the Qur'an is written. These show that in Islamic perspective, toilet is regarded as dirty place so people should not bring sacred things there. There is no concept of toilet in Jannah (Heavens), because Jannah is the purest of spaces in the Muslim imagery. Toilets are consructed that the directon is not toward Mecca, and it is said that one should not talk or sit for a long time in the toilet.

There are certain prayers to enter a toilet and after elimination. Before entering the toilet one shall say:

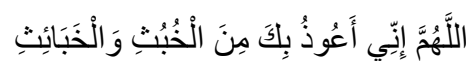

Translation: Oh God, I seek refuge in Thee from that which is evil (male) and that which is evil (female)! 
Once one is done with defecation and cleaned either with water or jammrah or clean smooth pebbles shall say:

$$
\text { الحمد لله الذي أذهب عني الأذى و عافاني }
$$

Translation: Praise be to Allah who relieved me of the filth and gave me relief.

\section{Toilet: Beliefs and Tradition in Japan}

From 14000 BCto $800 \mathrm{AD}$, people had been using toilet built on the river which was called “川屋 Kawaya (kawa = river, ya = house) “, and the word Kawaya is used as 則, the same pronunsation with different character nowadays too. In the $8^{\text {th }}$ century to the $12^{\text {th }}$ century, the nobles used wooden boxes called “樋箱 (Hibako)" as toilet. Sanitary facilities were improved during the $12^{\text {th }}$ century to the $19^{\text {th }}$ century as people have been used excrements as manure for agricultural products. Similar practices were prevalent among old Romans (Magness, 2012). Excrements from rich area was sold in high price because they ate good food which had better nutrious value.

Anthropologist Kumagusu Minakata mentioned in his ethnographic research in the South of Wakayama Prefecture, that people in that region had traditional custom when eye disease was plevalent, people pray God-of-the-Toilet. People offered incense in front of the toilet, and it was also believed that they could keep away from eye disease by making small red flags as many as the number of the family members and hoisted these flags on the wall of the tiolet. They said the God-of-the-Toilet was blind, so he would be happy if they clean the toilet. It was also believed that if a pregnant woman cleans the toilet, she would be able to have a beautiful baby.

It is still widely believed that if a woman cleans toilet very well, she will be able to have a beautiful child in the future. Cleaning toilet is also regarded as a way of mental training, so pupils clean the toilets of school on their own. In addition to it, in some companies, workers have duty to clean toilet. It is because people think one cannot do great work if he/she cannot do small work like cleaning toilet.

\section{METHODOLOGY}

For attitude and behavioral survey, questionnaires were distributed to the people in both Pakistan and Japan. Questionnaire was composed of mix of close-ended and open-ended questions. Same questions were asked in English and Japanese; format was kept easy so that participants could easily understand, comprehend, and respond. For the Japanese participants, questionnaires were sent via e-mail in which the link of the answering form was attached. Researcher's e-mail address was also mentioned, so each Japanese participant could ask researcher via e-mail in case they did not understand the question. For Pakistani participants, researcher distributed questionnaire in the same manner, but it was not successful. Interlocutors were told that their responses would be treated anonymously, and their privacy would be strictly protected. Questionnaire was reviewed within a small circle of peers and shortcomings were ratified, for example, it was pointed out that the word "BGM" was not popular among ordinary people, so later on it was mentioned as "background music" to avoid confusion. For better explanation, photos of sitting toilet and squat toilet were attached to the questionnaire. Concerning that this questionnaire asked very personal matter and it had expected that Pakistani people might feel the hesitation to answer it, researcher chose to distribute questionnaires to the people by clicking the link so that they did not need to meet researcher. However, later the Pakistani research partner conducted conversational interviews with Pakistanis. Therefore, the results from survey are augmented with the learning from those conversational interviews.

Eligibility criteria for the interlocutors were age and literacy, minimum of 20 years of age was required. The respondents were selected as convenient sampling on voluntary participation basis. The key aspect of this research is to compare the people's attitudes toward the use of toilet, so to fulfill the purpose and given that it was just small-scale research; even the small sample will suffice. 10 Pakistanis, and 14 Japanese participated in the survey and five conversational interviews were conducted in addition.

\section{RESULTS}


Exploring The People's Attitude and Behavior in The Toilets in Pakistan and Japan

The survey questionnaire responses are not national representative; however, the results help to highlight the general tendencies of behavior and attitude towards toilet for at least literate youth.

Japanese responses of the survey are tabulated and pictorially presented in the appendices. Various responses show that Japanese do variety of things in toilet, not only excretion but also other activities such as using mobile, smoking cigarette, reading, and sleeping. One could easily observe that the respondents have not only bad image about toilet, but also have positive images like peaceful, safe, clean, and so on. The distribution of age was wide; from 20's to over 50's, and respondents are both male and female. Most of them use Western style toilet and they prefer it to Asian squatting style toilet; it is traditional style for Japanese though.

As for the age, $90 \%$ of the respondents from Pakistan were in their 20 's, while more than $90 \%$ of Japanese participants are over 30 years old. It might be due to the peer references available to the researchers. $60 \%$ of Pakistanis use squat toilet and $70 \%$ of them like squat toilet to use. In the Japanese respondents, $92.9 \%$ of them use sitting toilet and all of them like sitting toilet, which means, nobody liked squat toilet, which is the big difference with the Pakistani result. However, in conversational interviews this result was confronted when the interlocutor argued that it might be because of the socioeconomic class of the Pakistani respondents, they may be from lower-middle class. The interlocutor mentioned that middle and upper-middle classes copy the rich and elite, therefore, they have western sitting toilets. Modern urban architecture in Pakistan is using western sitting toilets instead of traditional squat toilets which are still popular among peripheral neighborhoods of lower-middle income class.

As for the question what people do in the toilet on daily basis and what people have done in the toilet in the past, the top three answers of both two countries.

Pakistan

1. Changing clothes $-50 \%$

2. Using mobile $-40 \%$

3. Shaving hairs $-30 \%$

Japan

1. Using mobile $-84.6 \%$

2. Reading $-46.2 \%$

3. Smoking, being lost in fancies, and masturbation got same points $-38.5 \%$

Responding to the question about feeling hesitant to talk about excretion, only $20 \%$ of the Pakistani respondents answered that they do not feel any hesitation, while others answered that they do feel hesitation, do not know, or even do not like to answer. $71.4 \%$ of Japanese respondents answered that they do not feel any hesitation when talking about excretion, and only $14.3 \%$ answered that they do feel hesitation.

As for the question about what people regard to be important about toilet when they use the toilet, both Pakistani and Japanese respondents answered that cleanliness is the most important. Japanese respondents also answered that it important if the toilet is free or charged (64.3\%), however none of the Pakistani respondents regarded that important. This might be an indicator of frequency of use of paid public toilets.

In the question: "what kind of image do you have about lavatory/ toilet/ rest room?", Pakistani respondents answered (1) Clean-50\%, (2) Dirty-40\%, (3) Comfortable-30\%. Japanese respondents answered (1) Smelly-71.4\%, (2) Cold-57.1\%, (3) Dirty-50\%. (Respondents were asked to check the all choices which were relevant to their images, so the percentage reached over $100 \%$ in total.)

Two open-ended questions were asked in the questionnaire: if they can tell any stories about good/bad experience when using toilet, and if they can tell the opinion or idea concerning about toilet, and could receive some interesting answer. For example, one of the Pakistani wrote that he/she fell down in the toilet as the floor was wet. One from Japan wrote that he/she had a dream that when opened the toilet door, it was directly connected with a teachers' room of the school. Many mentioned of the dirtiness of the public toilets. Someone also mentioned that he witnessed someone's sexual activity in a public 
toilet. There was an opinion that one shall be able to use toilet to wash the pet dogs. One Pakistani girl reported of having UTI (Urinary Tract Infection) after using a public toilet and she avoids public toilets from that day.

\section{DISCUSSIONS}

Our initial assumptions were that there might be diversities in the use of toilet, not only for excretion, changing napkins (in the case of women), doing masturbation, vomiting in the case they were not feeling well, but also some other purposes like using mobile, reading newspaper, and so far. Cleanliness of the toilet is necessary for the diversity of the toilet use, simply because nobody wants to stay longer if the place is dirty. In my (Kondo) personal experience, most of the toilets in Japan are clean. Of course there were some exceptions, as one respondent from Japan mentioned that the public toilet is often very dirty. However, since my toilet experience here is not so good, for example, the public toilet in the Pakistan monument was very dirty, so everyone there were complaining about the wet floor and the bad smell. In this regard, I had thought that there might be more diversity in toilet use in Japan as it is cleaner than the toilets in Pakistan. However, the result of the research showed that the people in Pakistan also use toilet in the various way. In both countries, people use mobile phone in the toilet to send text message, or to check their accounts on social networking sites; such as Facebook, twitter, and so on: in Pakistan, $40 \%$, and in Japan $84.6 \%$. The less use of cell phone in Pakistan might be because there is water in the toilet and people are afraid that their cell phone may get water inside and malfunction. The tendency that people use mobile very often, or all the time is international. According to Panasonic, in 2012, about 90 to $95 \%$ of all phones sold in Japan were waterproof, so customers could use the mobile in the bathroom without worrying it to be broken. $50 \%$ of Pakistanis answered that they change clothes in the toilet and this is the high rate in the results, while it was only $30.8 \%$ in Japan. This may be because people use modular bathroom in which toilet and shower are in the same room in Pakistan. In Japan people change clothes in a dressing room next to bathroom so they usually do not change clothes in the toilet. Or, there is the case that women change clothes in the toilet after work, often suit to dress, to go to party or restaurant/bar at night. The space and structure maters a lot and where the toilet is positioned in the house and in the public spaces. $30 \%$ of Pakistani respondents answered that they shave hairs in the toilet, while it was $0 \%$ in Japanese respondents. This may be due to the difference in the structure of the toilet.

Since there is less space in Japanese toilet, people hardly shave body hairs in the toilet, on the other hand, people have enough space and water is also available to wash the shaved hair away in Pakistani toilets. However, shaving often causes clogging in Pakistani toilets. There are religion oriented practices, a hadith quoted in Sahih al-Bukharis mentioned that Abu Huraira narrated, "I heard the Prophet saying, Five practices are characteristics of the Fitra: circumcision, shaving the pubic hair, cutting the moustaches short, clipping the nails, and depilating the hair of the armpits." So the difference of religious background brought the difference in the answers of both sides. Another big difference is, only one person answered that he smokes cigarette in toilet in Pakistan, $38.5 \%$ of the people in Japan answered that they smoke cigarette in the toilet. In Japan, smoking on the street is prohibited in many selfgoverning bodies. In most universities, hospitals, baseball stadiums, and train stations smoking is also prohibited or smokers need to go to the limited area where it is allowed. Most restaurants and cafeterias are no smoking. In addition to it, non-smokers, who are majority of the population, have bad image to smokers, so very often smokers feel as if they are isolated. They have to hide themselves when they smoke, so they use the toilet as it is the best place that they can smoke without be blamed by other people.

Some respondents also answered that they masturbate themselves in the toilet (Pakistan: $10 \%$, Japan: $38.5 \%$ ) Some respondents answered that they had sex in the toilet or they saw someone was doing sexual activities in public toilet. Most Pakistani respondents answered that they feel hesitation when talk about excretion or do not want to answer weather it was yes or not. Most Japanese $(71.4 \%)$ answered that they do not feel any hesitation in talking about excretion, one reason might be because of the difference in religious background as mentioned in literature review. However, do not feel any hesitation to talk about 
Exploring The People's Attitude and Behavior in The Toilets in Pakistan and Japan

excretion does not mean that they can talk openly in public, of course. Even though we see excretion every day, at most of the occasions it is taboo to talk about (especially when we are eating something). However, children are socialized by toilet training as they can build the sense of independence and privacy. People, generally speaking, go to the toilet which is the separated room to excrete, and by flushing water, one can hide his/her excretion from other people. These activities are very private, although it was not always so, for instance roman elite had communal toilets where they socialized while defecating. The concept of self or individual starts; when a person starts to have his or her own secrets which he or she do not want to share with other people, so after learning how to use toilet, child can be conscious of self and other, so he/she feels shame about the act of excretion. In open-ended questions, one mentioned that his sister was worried if someone takes photos of others when they are in the toilet. Other mentioned that he was surprised when seeing other was using toilet paper differently because in general we do not have any opportunity to see how other people act in the toilet. We all may have experience that when we opened the toilet's door and find someone was inside, or someone opened the door of the toilet when we were using it. We do feel hesitation when we see other's using toilet or when we are seen by others while using toilet. Since people regard that the act of excretion is highly private behavior, there are some people who have particular sexual orientation and want to see other people's act of excretion. Most of the case, this is regarded as criminal in developed nations.

The most interesting finding in this research is, the result of the question which asked what kind of images people have toward toilet. In both countries most people think it is dirty (Pakistan; 40\%, Japan; $50 \%$ ). But Pakistani also answered that they have image of clean $(50 \%)$, comfortable $(30 \%)$ - we can regard that these are positive image, while Japanese participants have negative images such as smelly $(71.4 \%)$ and cold $(57.1 \%)$. The results of the survey showed that people think the most important thing about toilets is cleanliness.

Pakistani people often avoid paid toilets. There might be many reasons that could be speculated. First thing is about spending habit. Given that people spend less on paid public toilets and government or city administration do not have the public toilets on their priority, they are neglected and so is the cleanliness, consequently masses avoid using dirty public toilets and the revenue is not generated by these toilets. Pakistani government does not penalize anyone who urinates in the public spaces (for example next to a tree or a wall), therefore, the men do so to save money and avoid dirty toilet. Many public toilets where sitting toilets are installed are overtly show the shoe marks on the seat that reflects that people use sitting toilets as squat toilets by sitting on the seat in squat position with shoes on the seat.

In personal conversations reasons, that most of the Pakistanis who received the questionnaire refused to respond; even though it was announced that it would be anonymous and their privacy will be strongly protected, were exclaimed. Some of them told that it was socially considered as taboo, and educated people have quite high-pride, so that they want to hide such thing which can be regarded as dirty or 'not so cool' to say to other people. Initial resistance to fill survey questionnaire might be the xenophobic reaction, it might be possible that people felt wariness when they heard that it is a foreigner and female, whom they did not know so closely, needed to conduct research to gather data, as most people in Pakistan are conservative. However, they did respond when a Pakistani, male, and they had been knowing him well, asked them to answer the questionnaire.. So we can conclude that there might be mental barrier when the questionnaire was distributed by an unknown person while it could be easier when it was distributed by the native or an insider.

\section{CONCLUSION}

Society forms the cultural norms, taboos, and laws for the people living in the society. However, there are different in different societies, so it may be possible that in some society something is considered as taboo, while in other society it may be regarded as normal thing. It also changes with time, so it might be possible that some people regard something as taboo, while younger generation have different feeling from their elders. 
This research showed the difference of people's behavior in the toilet in two countries, and it also showed what kind of images people have about the toilet and excretion, and it was also diverse in the response in different countries. The factors which create such diversity is obviously their cultural background such as religion, traditions, modernization, or westernization. We also can say that if sanitary condition gets improved, people become to feel comfort to use toilet so they may use the space in different other way too.

\section{BIBLIOGRAPHY}

(NHA), N. H. (2004). National Highway Authority Regulatory Framework and Standard Operating Procedures for Preservation and Commercial Use of Right of Way (ROW) - 2002. Islamabad: Road Asset Management Division (RAMD).

(2005). Lessons Learned from Bangladesh, India, and Pakistan-- Scalling-up Rural Sanitation in South Aia. The World Bank.

Coombes, R. (2010, September 18). Toiling for Toilets. British Medical Journal, 341(7773), 582-583.

Khawar, H. (2016, July 27). Toilets and Public Policy. Toilets and Public Policy(ePaper). The Express Tribune . Retrieved January 8, 2022, from https://tribune.com.pk/story/1150759/toilets-publicpolicy

Kurniawan, E. (2008, October). Graffiti in the Toilet. (B. R. Anderson, Ed.) Indonesia(86), Indonesia.

Magness, J. (2012, June). What's the Poop on Ancient Toilets and Toilet Habits? Near Eastern Archaeology, 75(2), 80-87.

Overall, C. (2007, Fall). Public Toilets: Sex Segregation Revisited. Ethics and the Environment, 12(2), 71-91.

Pathak, D. B. (1995, March). Sulabh International Museum of Toilets. Retrieved from History of Toilets: Exploring history of sanitation \& hygiene: http://www.sulabhtoiletmuseum.org/history-of-toilets/

Szczygiel, M. (2015). 日本がトイレ大国になれたのはどうして?大阪大学人間科学研究科文化社 会学 アルザス日欧知的交流事業日本研究セミナー「日常生活文化」報告書. 大阪.

Valerie Curtis, Adam Biran. (2001, Winter). Dirt, Disgust, and Disease - Is Hygiene in Our Genes? Perspectives in Biology and Medicine, 44(1), 17-31.

Warner, W. S. (2004). Cultural Influences that Affect the Acceptance of Compost Toilets: Psychology, Religion and Gender. Jordforsk Center for Soil and Environmental Research, As, Norway.

南方熊楠. (2009). 南方熊楠コレクション〈第 2 巻〉南方民俗学. (中. 新一, Ed.) Tokyo, Japan: 河出 書房新社. 
Questionnaire (English)

\section{APPENDICES}

Please check the answer of your choice or write in the space provided. Your privacy is protected, and it would ever identify.

1. Age:
$\square 20-24$
$25-29$
30-39
40-49
50- onwards

2. Gender:
$\square$ Male
$\square$ Female
Other

3. Which type of toilet do you use mostly?
$\square$ Sitting toilet (*Western style)
Squat toilet (*Asian style)

Other (

4. Which type of toilet do you feel comfort when use it?
$\square$ Sitting toilet (*Western style)
Squat toilet (*Asian style)
$\square$ Other (

5. What do you do in the lavatory/rest room (except excretion and changing sanitary napkin)? And what have you done in the lavatory/rest room? Check all the choices bellow. Lavatory/rest room here is different from the separated room with toilet, so washstand and other public space are not included.
$\square$ Using mobile (phone-call, text, SNS)
Changing clothes
$\square$ Cleaning the toilet
Meditation
$\square$ Selling/buying drug
Listening music
$\square$ Bullying someone
$\square$ Sleeping
Make-up
Stretching
$\checkmark$ Childbirth
$\square$ Smoking cigarette
$\square$ Shaving hairs
Reading (book, newspaper etc.)
Others
$\square$ Having sex
$\square$ Game
Being lost in fancies
$\square$ Eating
in fancies
turbation

(

6. Do you feel any hesitation when you talk about excretion?
$\square$ Yes
$\square$ No
Don't know
$\square$ Don't want to answer

7. What are the important things for you about toilet? Check all the choices below.
$\square$ Cleanliness $\square$ Color of the wallpaper $\square$ Background music
$\square$ Charged or free
$\square$ Design
$\square$ With bidet functions or not

8. What kind of image do you have about lavatory/rest room/toilet? Check all the choices below.
$\square$ Dirty
Enjoyable
Exciting
$\square$ Relaxing
$\square$ Smelly
$\square$ Cold $\quad \square$ Warm
$\square$ Comfortable
$\square$ Dark
$\square$ Light
$\square$ Shameful
$\square$ Funny
$\square$ Peaceful

\section{$\square$ Dangerous $\square$ Clean $\quad \square$ Other}

9. Can you tell me any stories about your good/bad experience when using toilet? If yes, kindly write the detail.

(

10. Finally please write freely about your opinion, idea, etc. concerning about toilet.

Thank you very much! 
Questionnaire (Japanese)

以下の該当する項目にチェックを付けて下さい。あなたのプライバシーは厳守されます

一.あなたの年齢は?
$\square 20-24$
$\square$ 25-29
30-39
40-49
$50-$

二.あなたの性別は?

$\square$ 男性

$\square$ 女性

$\square そ の$ 他

三. 普段家で使っているトイレの形状は何ですか?
$\square$ 洋式
$\square$ 和式
四. どのタイプのトイレがー番好きですか
口洋式
$\square$ 和式
$\square$ その他 (
$\square そ の$ 他

五. あなたは通常トイレで何をしますか?（排泄と生理中の処置を除く。）また、何 をしたことがありますか? 当てはまるもの全てにチェックを付けて下さい。この 場でのトイレとは個室のみを指し、洗面所など共用部は含まれません。 口携帯電話を使う（通話、メール、SNS）、瞑想、麻薬の売買

口着替え

$\square$ 音楽を聴く

ロトイレの掃除

口仮眠

ストレッチ

ロいじめ

化粧

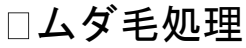

誌書 $($ 本、新罚

$\square$ 出産

$\square$ 喫煙

$\square$ 飲食

その他(

$\square$ 性行為

$\square$ ゲーム

妄想

新聞、など)

$\square$ 自慰行為

六. 排泄について語ることに抵抗はありますか?
ロはい
ロいいえ
○わかない
答えたくな
い

七.トイレの使用にあたって重視することは何ですか？（複数回答可）
口清潔さ
便器のデザイン
壁紙の色
$B$ GM
ロウオッシュレット
付きかどうか $\square$ 無料か有料か
ロその他(

八.「トイレ」についてどんなイメージを持っていますか。当てはまるもの全てにチ エックを入れてください。

\begin{tabular}{|c|c|c|c|c|c|}
\hline 口污い & 口楽しい & $\square わ く わ$ & する & ロリラックス & \\
\hline 臭い & ～寒い & 口暖かい & 口快適な & 口暗い & 口明るい \\
\hline $\begin{array}{l}\square \text { 恥ずかしい } \\
\square そ の \text { 他 }(\end{array}$ & & $\begin{array}{c}\text { しろい } \\
\text { ) }\end{array}$ & 口平和な & 口危険な & 口清潔な \\
\hline
\end{tabular}

九.トイレの使用に関してよい、または悪い思い出はありますか?あればその旨を。

一○. 最後に、提案、ポリシー、意見などトイレに関してコメントがあればお願 いします。

ありがとうございました 
Two photos were attached with each questionnaire so the respondents can easily distinguish sitting toilet (Western style) from squat toilet (Asian style). These photos are the following:

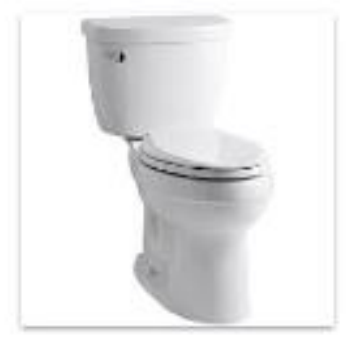

Squat toilet ( ${ }^{\star}$ Asian style)

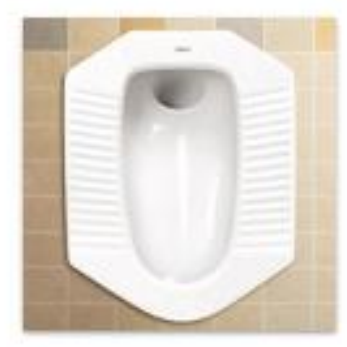

\section{Results of questionnaire}

\section{$\underline{\text { Pakistan }}$}

1. Age: (10 responses)

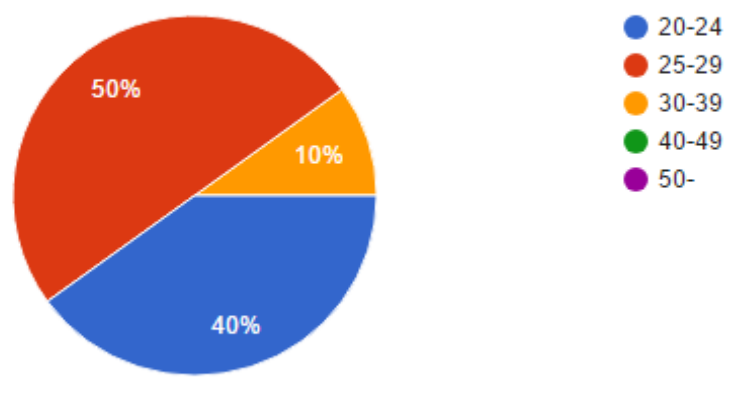


2. Gender: (9 responses)

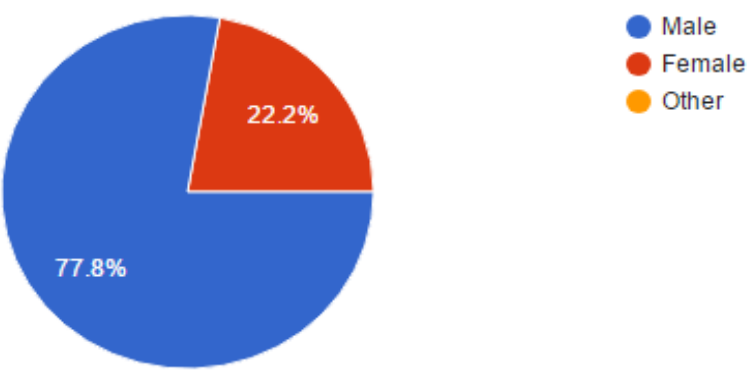

3. Which type of toilet do you use mostly? (10 responses)

4. Which type of toilet do y

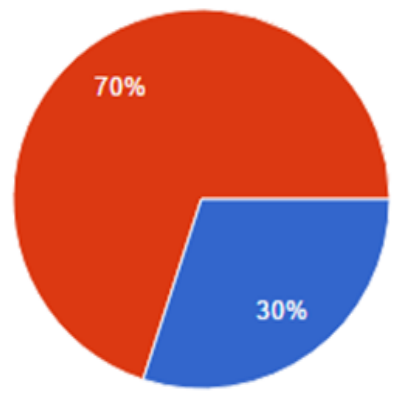

Sitting toilet (*Western style)

Squat toilet (*Asian style)

Other
$60 \%$

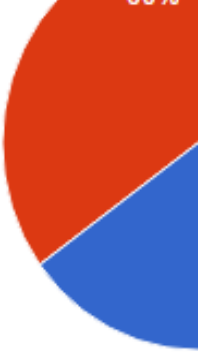


5. What do you do in the lavatory/rest room (except excretion and changing sanitary napkin)? And what have you done in the lavatory/rest room? Check all the choices bellow. Lavatory/rest room here differs the separated room with toilet, so washstand and other public space are not included.

(10 responses)

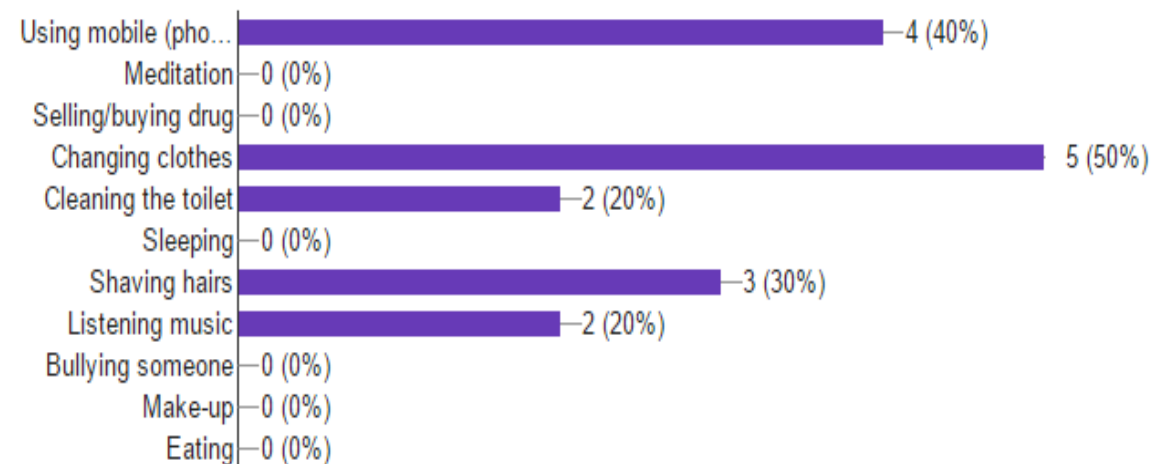

8. What kind of image do you have about lavatory/rest room/toilet? Check all the choices below.

(10 responses)

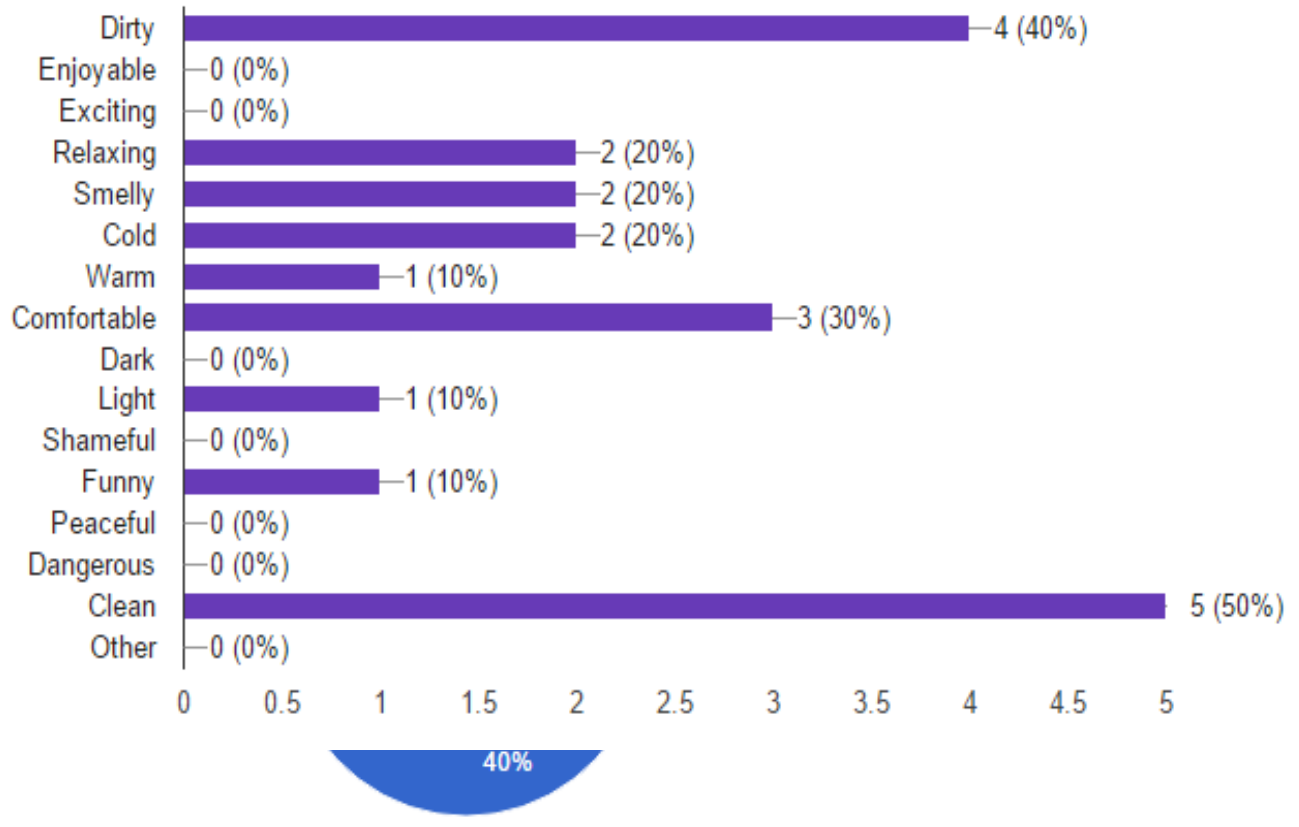

7. What are the impo below.

(10 responses)

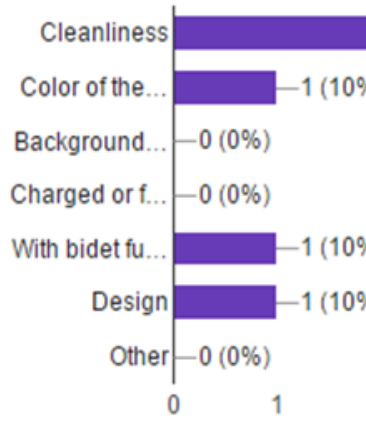


$\underline{\text { Japan }}$

1) Age

一.あなたの年齢は？ (14 responses)

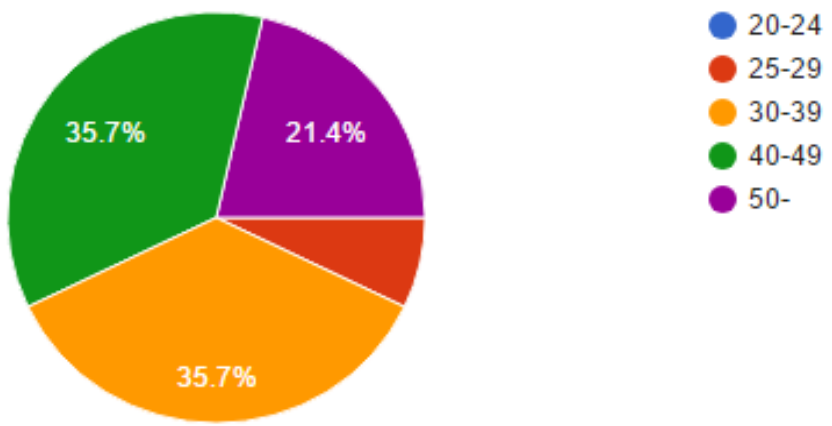

2) Gender

二.あなたの性別は？ (14 responses)

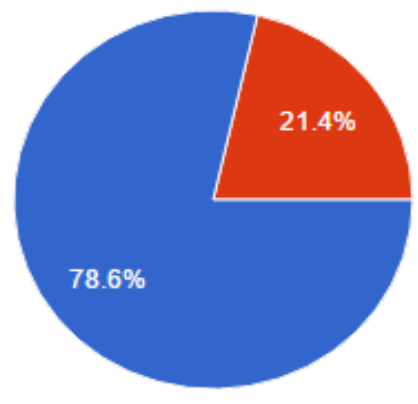

3) Which type of toilet do you use mostly? 
四. どのタイプのトイレが一番好きですか (13 responses)

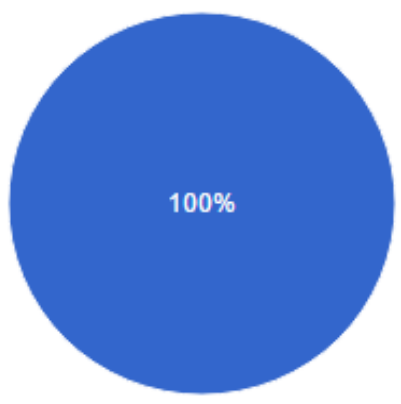

4) Which type of toilet do you feel comfort when use it?

5) What do you do in the lavatory/rest room (except excretion and changing sanitary napkin)? And what have you done in the lavatory/rest room? Check all the choices bellow. Lavatory/rest room here differs the separated room with toilet, so washstand

and other public

are

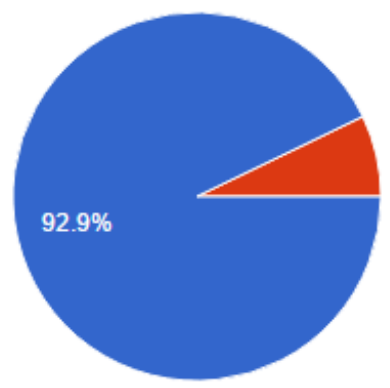
space not included. 


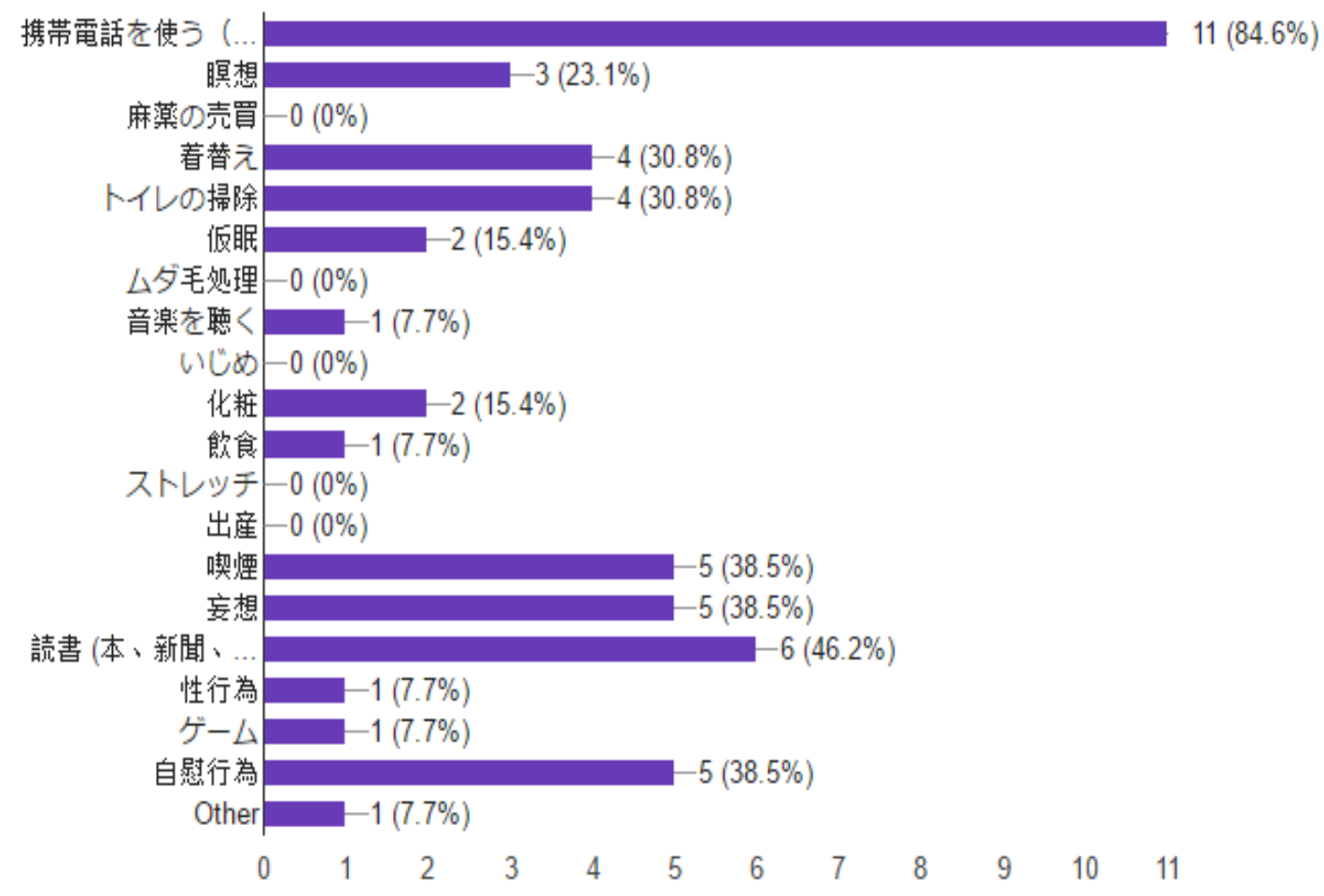

6) Do you feel any hesitation when you talk about excretion?

六. 排泄について語ることに抵抗はありますか？ (14 responses)

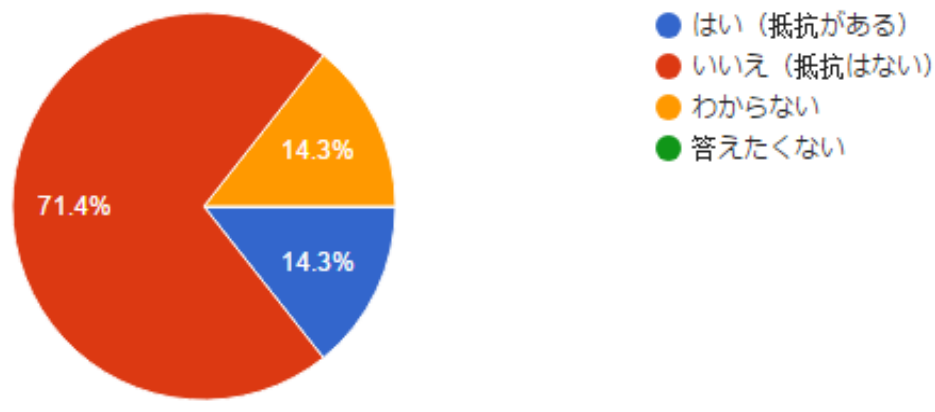

7) What are the important things for you about toilet? Check all the choices below. 
Exploring The People's Attitude and Behavior in The Toilets in Pakistan and Japan

七.トイレの使用にあたつて重視することは何ですか？（複数回答可） (14 responses)

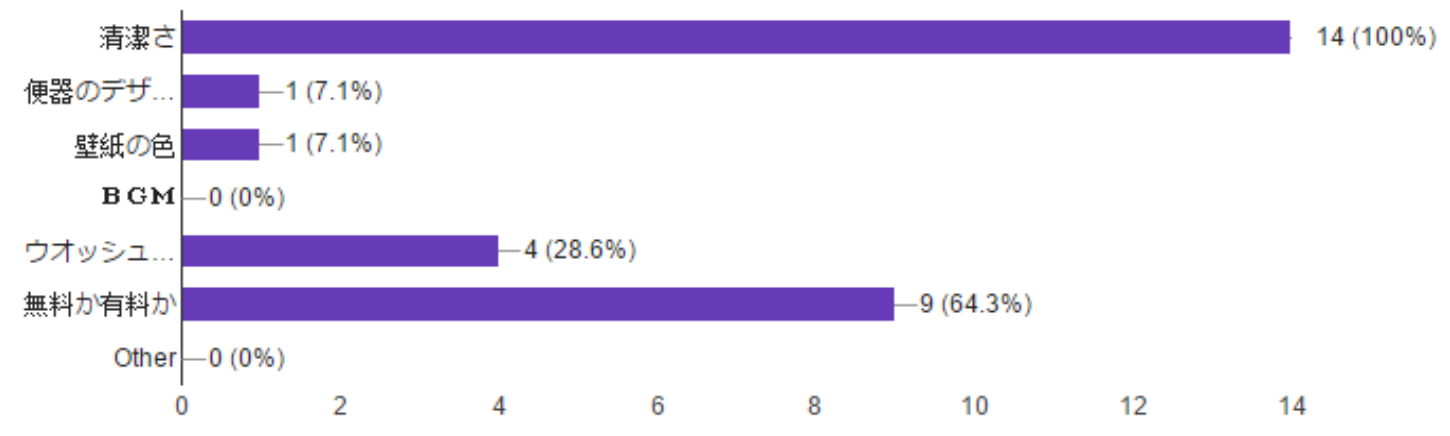

8) What kind of image do you have about lavatory/rest room/toilet? Check all the choices below. 
八.「トイレ」についてどんなイメージを持っていますか。当てはまるもの 全てにチェックを入れてください。

(14 responses)

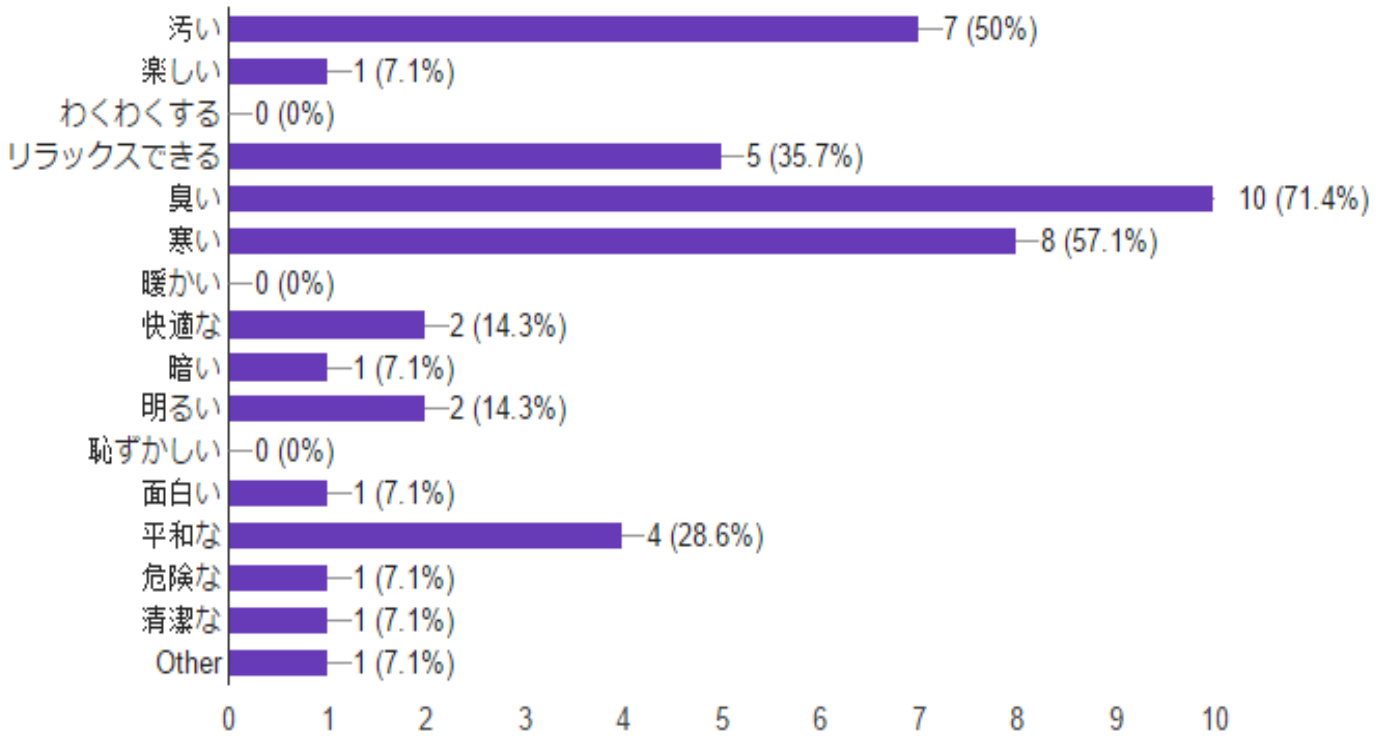

